\title{
The study of the antioxidant enzymes, the activity of acid phosphatase and alteration of lipid peroxidation in women with uterine tumors
}

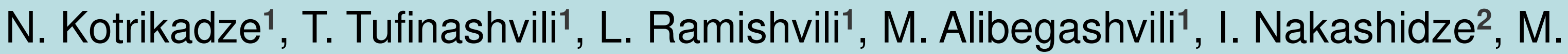 \\ Gordeziani' ${ }^{1}$, B. Sepiashvilli', S. Ahmad ${ }^{3}$.
}

${ }^{1}$ Ivane Javakhishvili Tbilisi State University, Department of Biology, Tbilisi, Georgia.

2Ivane Javakhishvili Tbilisi State University, Scientific-Research Institute of Cellular and Molecular Medicine, Tbilisi, Georgia.

${ }^{3}$ Florida Hospital Cancer Institute, Department of Gynecologic Oncology, Orlando, FL, USA

Objectives: It is well known that intensification of steroid hormones and lipids peroxidation reflect on the membrane of the lysosomes. Isolated lysosomal enzymes in a pathological condition, create the radicals and promote the induction of cell damage and decrease the activity of antioxidant enzymes. We aimed to investigate the alteration of enzymatic activity of antioxidant enzyme - superoxide dismutase (SOD) and catalase (CAT). Also, we study membrane enzyme - acid phosphatase activity (AP) and alteration of lipid peroxidation intensity among the menopausal women with uterine benign (myoma) and malignant (endometrium cancer) tumors

Methods: For the study Blood samples from uterine benign $(n=15)$ and uterine malignant $(n=15)$ cases were collected, along with healthy menopausal (control, $n=15$ ) women. Spectrophotometric methods were used for determination of the activities of blood antioxidant enzymes, as well as for the determination of the activity of acid phosphatase.

Results. Studies have shown that the activity of the antioxidant enzyme - SOD 1.6-times decrease within the benign tumor and $\sim 6$-times in endometrial cancer compared to the control group. The activity of catalase is low among women uterine tumors compared to the control group. Lysosomal enzyme - AP altered slightly in benign tumor and was 2-times elevated in malignant tumor compared to the control group. The intensity of lipid peroxidation was increasing $\sim 1,5$ times in benign and 2,2 times in malignant tumor compared to the control group.
Conclusions: On the background intensification of lipid peroxidation ongoing enhanced use of antioxidants, that reflects on the alteration of organism' antioxidant system activity.

Table 1. Antioxidant enzymes, the activity of acid phosphatase and intensity of lipid peroxidation alteration in Women with Uterine Tumors

\begin{tabular}{|c|c|c|c|}
\hline Enzymes & $\begin{array}{c}\text { Control } \\
\text { group }\end{array}$ & $\begin{array}{c}\text { Benign } \\
\text { tumor }\end{array}$ & $\begin{array}{c}\text { Malignant } \\
\text { tumor }\end{array}$ \\
\hline $\begin{array}{c}\text { Superoxide } \\
\text { Dismutase } \\
(\mathbf{U} / \mu \mathrm{l})\end{array}$ & $1 \pm 0.2$ & $0.61 \pm 0.1$ & $0.17 \pm 0.05$ \\
\hline $\begin{array}{c}\text { Catalase } \\
\text { (mcat/ml) }\end{array}$ & $1 \pm 0.2$ & $0.72 \pm 0.15$ & $0.21 \pm 0.06$ \\
\hline $\begin{array}{c}\text { Acid } \\
\text { phosphatase } \\
(\mathbf{U} / \mu \mathrm{l})\end{array}$ & $1 \pm 0.1$ & $1.1 \pm 0.25$ & $1.8 \pm 0.2$ \\
\hline $\begin{array}{c}\text { lipid } \\
\text { peroxidation } \\
(\boldsymbol{\mu M} / \mathrm{L})\end{array}$ & $6 \pm 0.13$ & $10 \pm 0.32$ & $13 \pm 0.41$ \\
\hline
\end{tabular}

